\title{
ユニバーサルロボットハンドのための分布型圧カセンサの開発*
}

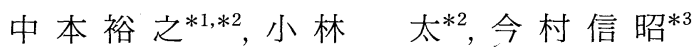 \\ 白沢秀則 ${ }^{* 4}$, 小島史男 ${ }^{* 5}$
}

\section{Development of Pressure Distributed Sensor for Universal Robot Hand}

\author{
Hiroyuki NAKAMOTO*6, Futoshi KOBAYASHI, Nobuaki IMAMURA, \\ Hidenori SHIRASAWA and Fumio KOJIMA
}

\author{
${ }^{* 6}$ Hyogo Prefectural Institute of Technology, \\ 3-1-12 Yukihira-cho, Suma-ku, Kobe-shi, Hyogo, 654-0037 Japan
}

\begin{abstract}
We propose a pressure distributed sensor as a tactile sensor for a five-fingered robotic hand like a human hand. The sensor has simple, three-layer structure, which composed of an urethane gel, a pressure sensitive rubber under the gel, and an electrode sheet at the bottom. The arrangement brings high productivity and smooth maintenance. The electrode sheet also provides high ratio of the detection area to the sensor and high sensitivity. First, the characteristics of response time and accuracy are investigated by ground tests. Secondly, a shape recognition method with the sensor is proposed. Finally the effectiveness and validity of the proposed method are demonstrated through laboratory experiments.
\end{abstract}

Key Words : Sensor, Recognition, Robot, Pressure Distribution, Robot Hand, Shape Recognition

\section{1. は じめ に}

これまで多数の人間協調・共存型ロボット ${ }^{(1)}$ が発表 され，それらは極限作業から家庭内の家事まで幅広く 人間を補助できるものと期待されている. しかしなが ら，そういったロボットに人間が行っているような多 種多様な作業を可能とさせるためには, 未だ多くの研 究開発要素がある. その一つとして, 人間の生活環境 において，人間の使う道具を使いこなすことが可能な ロボットハンドが挙げられる，このハンドは，人間の 手と同等の大きさと機能を備えることが望ましい. 人 間の手のように多関節の指を複数本もつハンドの研究 例として, MEL Hand ${ }^{(?)}$, Utah/MIT Dextrous Hand ${ }^{(2)} ゃ$ Gifu Hand ${ }^{(3)}$ などの研究がある.これらの研究に扑て は, 主に力覚センサと関節角度センサを用いた制御手

* 原稿受付 2007 年 11 月 20 日.

*1 正員, 兵庫県立工業技術センター(䡤 654-0037 神戸市須磨 区行平町 3-1-12).

*2 正員, 神戸大学大学院工学研究科(正 657-8501 神戸市灘区 六甲台町 1-1).

*3 正員, 広島国際大学工学部(画 737-0112 吳市広古新開 5-11).

*4 (財) 近畿高エネルギー加工技術研究所 (要 660-0083 尼崎市 道意町 7-1-8)

*5 正員, フェロー, 神戸大学大学院工学研究科.

E-mail : nakamoto@ hyogo-kg.go.jp
法の提案等が行われているが，実作業を可能とするた めに，それらセンサだけでは不十分だと考えられる. ロボットハンドが器用な動作を実現するためには, 把 持物の形状や位置、方向などの認識が必要である.

一方，人間の皮膚には触覚があり，触覚は作業を行 うために重要な役割を担っている(4). そして, 人間の 皮膚は柔軟であり，そのことが物体との柔軟な接触を 可能にしている．このような人間の皮膚の特性から， センサ素子の研究例として, 非線形弾性を利用して表 面応力の強さと広がりを計測するセンサ ${ }^{(5)}$ や，構造の 弾性・粘性変化を利用した高感度で測定範囲の広い在 電振動型触覚センサ(6)など多くの研究, 試作が進めら れている.これらの研究では主にセンサ単体に対する 評価がなされているが，ロボットハンドに適用した上 での実験や計測結果の処理方法の検討は十分になされ ていない，また，多指ハンドの指先へ適用できる柔軟 な触覚センサとして，エッジ方向の計測が可能な柔軟

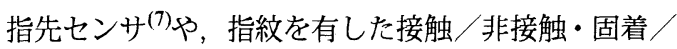
滑り分布の検出が可能な弾性ロボットフィンガ ${ }^{(8)}$, 人 間型柔軟指 ${ }^{(9)}$ など指先で用いるセンサの研究がある. また，筆者らは，接触面に柔軟な素材を用いることで， 
産業用ロボットの指先で円筒の直径を認識可能な分布 型圧力センサを提案した ${ }^{(10)}$.これらの研究では指先 に特化しており，指先以外の部位まで拡張し手全体を 使った研究まではなされていない，触覚センサを備え るロボットハンドに関する研究として, 接触力制御 ${ }^{(1)}$ やペン回し動作 ${ }^{(12)}$ などがある.このような研究例は 少ないが, 設計の段階よりロボットハンドへ搭載する ことを考慮し，ロボットハンドへ搭載した状態で評価 実験を行うことは, アプリケーションに即したハード ウェアとソフトウェアの両面の向上を図ることができ る点で, 触覚を備える実用的なロボットハンドの実現 に重要であると考えられる.

そこで本稿では, 人間の手と同様に 5 本の指をもつ ロボットハンド (以下, ユニバーサルロボットハンド とよぶ）に適用することを目的として開発した柔軟な 分布型圧力センサについて述べる. この分布型圧力セ ンサは，ウレタンゲルを用いた柔軟な表面層をもち， シート状の素材のみからなる単純な構造である点に特 長がある. さらに，センサ面積に対する検出面積の割 合を高くし，限られた面積の中で高感度となるような 設計を行っている. また，センサの基礎特性として， ユニバーサルロボットハンドへ搭載し，計測精度と忘 答速度に関する評価実験を行い，その結果を述べる. さらに，ユニバーサルロボットハンドが把持状態を認 識するために必要な接触面の形状を評価する方法と, その評価実験の結果について述べる.

\section{2. 分布型圧カセンサ}

2.1 構造開発した分布型圧力センサを図 1 に 示す．この分布型圧力センサは，物体に接触する面か ら順に, ウレタンゲル（(株) エクシールコーポレー ション製)，感圧導電性ゴム (イナバゴム (株) ${ }^{(13)}$ 製)， 電極シートの 3 層からなる. このように単純な 3 層構 造によって, センサ自体の製作や摩耗しやすいウレタ ンゲルの交換が容易となる. ウレタンゲルは, スポン ジ硬度が 15 であり, 厚さが $2.5 \mathrm{~mm}$ である. 物体が接 触すると，そのときの応力と接触面の形状からウレタ ンゲルが変形し, その変形によって感圧導電性ゴムに 加えられる圧力分布が決定する. 感圧導電性ゴムは, 厚さが $0.5 \mathrm{~mm}$ であり, 圧力を受け体積が減少すると シート内に配合される導電性の粒子が接触することか ら，その部位の電気抵抗值が小さくなるという特性を もつ. したがって, 電気抵抗值を計測することで, そ の部位に加えられている圧力を求めることができる. また, 電極シートとして, ポリイミド素材のフレキシ ブル基板にパターンを構成したものを製作した.

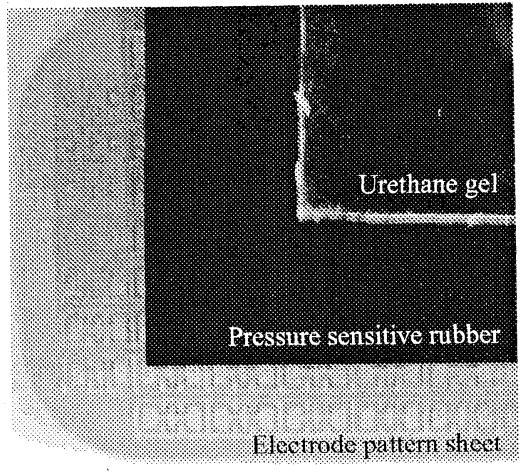

Fig. 1 Photo of Developed Pressure Distributed Sensor.

次に，電極シート上の電極パターンについて述べる. 電極では感圧導電性ゴムの電気抵抗值を計測するため, 電圧を加える電極 (以下, 電極 A とする) と電圧を加 えた際に流れる電流を受ける電極 (以下, 電極 B とす る）の 2 種類の電極をパターン化する必要がある. 文 献 ${ }^{(10)}$ ではその 2 種類の電極を別のシート上で製作し, 2 枚の電極シートで感圧導電性ゴムを挟み込む構造と した. 本研究では構造の簡素化と省線化のため, 複層 のフレキブル基板 1 枚の上に 2 種類の電極をパター ン化した. 製作した計測点 1 点分のパターンを図 2 に 示す. 図 2 において, 黒色の外周部分が電極 $\mathrm{A}$, 内側 の灰色部分が電極 $\mathrm{B}$ であり, 大きさは縦 $\mathrm{x}$ 横で $3.4 \mathrm{x}$ $1.8 \mathrm{~mm}$ である. また電極 $\mathrm{B}$ 中に2 つあるスルホール は, 電極 $\mathrm{B}$ をフレキシブル基板の中間層へ導通させて 抢り, 電極 $\mathrm{B}$ はその中間層で配線する. 感圧導電性ゴ ムはパターンの上に接触させて配置する. したがって, このセンサでは電極 $\mathrm{A}$ と B の両電極間にある白色の 電気的絶縁部分 (以下, 絶縁部とする) の上にある感 圧導電性ゴムが主な計測部分となる. 感圧導電性ゴム の変形によって, パターン上には感圧導電性ゴム内の 導電性粒子の接触による導電経路が複数できるが, そ の導電経路が多くできるほど電気抵抗值の変化が大き くなり分布型圧力センサとしての感度が高くなる.こ れを実現するには, 電極 $\mathrm{A}$ と B が近づくよう絶縁部 の幅を小さくし, さらに絶縁部を長くすれば良い，そ こで, 図2で示すパターンでは, 感度を高める目的で, 絶縁部の幅を安定して製造できる最小值である $0.2 \mathrm{~mm}$ とし, さらに絶縁部が長くなるよう各電極を凹凸状に 入り組んだ形状に設計した。

分布型圧力センサ 1 枚分のパターンを図 3 に示す. このパターンでは, 縦方向に 9 本の電極 $\mathrm{A}$ を配置し, 横方向に 12 本の電極 B を配置する．このパターンに は図2で示したパターンが 102 点あるので, 計測点も 


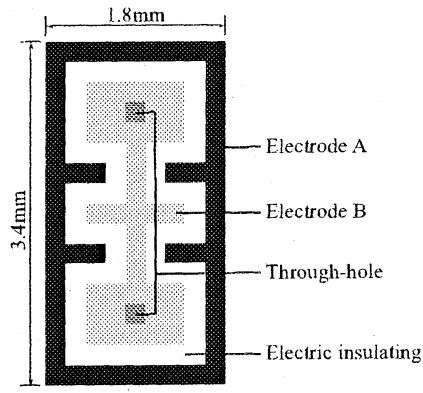

Fig. 2 Unit of electrode pattern.

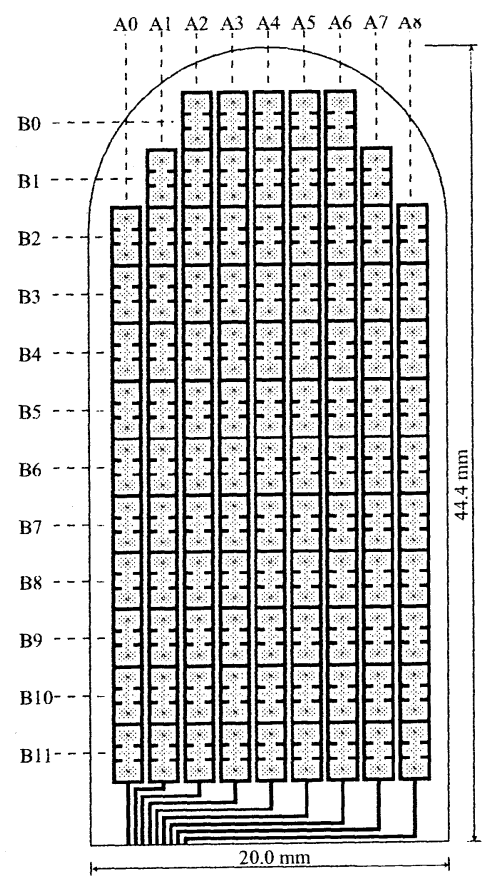

Fig. 3 Sheet of electrode pattern.

102 点である. このパターンでは, 物体が分布型圧力 センサに接触したとき力を検出できない面積をできる だけ少なくするため, 計測点間（電極 A 間）の間隔を $0.2 \mathrm{~mm}$ に設計した. その結果, 全パターン面積に対す る計測点面積の割合は約 $80 \%$ \%てる.

$2 \cdot 2$ ユニバーサルロボットハンドへの適用 分 布型圧力センサを適用したユニバーサルロボットハン ドを図 4 に示す.ユニバーサルロボットハンドは，5 本のフィンガから構成されており, 各フィンガは 3 つ のリンクと 4 つの関節をもつ. 分布型圧力センサを フィンガの各リンクの指の腹側の 3 部分に貼り付けて おり, 計測点数は指先に図 3 で示した 102 点, 他の 2 部分が 70 点である. 各分布型圧力センサからの配線 は，幅約 $10 \mathrm{~mm}$ のフレキシブル基板で指の関節の隙間

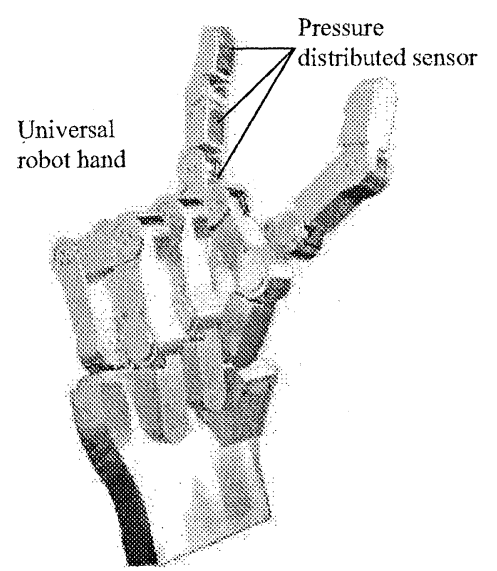

Fig. 4 Universal robot hand with developed sensors.

を通じてロボットハンドの背に配置した.さらに配線 は，センサ制御回路を経由して OS が RT-Linux であ る $\mathrm{PC}$ 上の $\mathrm{AD}$ 変換ボード, $\mathrm{DIO}$ ボードに接続される. センサ制御回路はマルチプレクサ回路とアンプ回路で 構成される.PC は DIO ボードを介して, マルチプレ クサ回路に対して計測点の指定ができる. したがって, 全点計測の場合, 任意の順で計測することが可能であ るが, 主に図 3 の左上から右下の計測点に向けて一行 ずつ計測を行ない圧力分布として取得した. マルチプ レクサ回路は, 指定された計测点の電極 $\mathrm{A} に 5 \mathrm{~V}$ の電 圧を加え, 指定された計測点の電極 $\mathrm{B} に$ 流れた電流 をアンプ回路により $0 \sim 10 \mathrm{~V}$ の電圧值に変換する.こ の電圧值の範囲は, 感圧導電性ゴムの電気抵抗值の変 化で約 $20 \mathrm{M} \sim 5 \mathrm{k} \Omega$ 分に相当し, これは計測点 1 点で 計測する力の約 $0 \sim 1 \mathrm{~N}$ に相当する. PCはマルチプレ クサ回路, $\mathrm{AD}$ 変換ボードを介し, この電圧值を $12 \mathrm{bit}$ の分解能，0４095 の值で取得する. なおセンサ制御 回路では, 零電位法 ${ }^{(14)}$ を用いて電流の回り込みを防い でいる. 以上のような構成で, 1 点の計測に約 $150 \mu \mathrm{s}$ を要し, 全点計測の場合は $20 \mathrm{~ms}$ の周期で圧力分布を 取得できる。

\section{3. 計測精度と応答速度}

$3 \cdot 1$ 力推定式とパラメータ決定方法 分布型圧 カセンサの評価実験として, 計測精度の評価を行った. ここでは, 分布型圧力センサで計測した力の和を, ロー ドセルの值と比較する.

まず，PCで計測した電圧值から計測点 1 点に掛かる 力を推定する式を考える. ただし, 計測した電圧值と その計測点 1 点に掛かる力の関係は, 感圧導電性ゴム の特性から非線形の関係にあるので，ここでは式 (1) 
のように 16 変数からなる 1 次方程式を考える.

$$
f=\beta_{0}+\beta_{1} x_{1}+\beta_{2} x_{2}+\cdots+\beta_{16} x_{16}
$$

ここで, $\beta_{i}(i=0 \ldots 16)$ は方程式の係数である. $x_{j}(j=$ $1 \ldots 16)$ は計測した電圧值を代入する変数であり, 計 測した電圧值 $(0 \sim 4095)$ を 16 分割し, $j$ が小さい $x_{j}$ から順に $0 \leq x_{1} \leq 255,0 \leq x_{k} \leq 256(k=2 \ldots 16)$ と 電圧值を代入する. 例えば, 電圧值が 1000 の場合, $x_{1}=255, x_{2}=x_{3}=256, x_{4}=233, x_{5}=\ldots=x_{16}=0$ と なり，これを式(1)に代入することで計測点に加えら れた力 $f$ を求める. また, 力 $f$ を求めるためには係数 $\beta_{i}$ を事前に求める必要があるが, この方程式を $f$ の変 数 $x_{j}$ に対する重回帰式とみなして次のように係数 $\beta_{i}$ を求める.

$(m+1)$ 個の変数 $F, X_{1}, \ldots, X_{m}$ について $n$ 組のデー 夕 $\left(f_{1}, x_{11}, x_{21}, \ldots, x_{m 1}\right),\left(f_{2}, x_{12}, x_{22}, \ldots, x_{m 2}\right), \ldots$, $\left(f_{n}, x_{1 n}, x_{2 n}, \ldots, x_{m n}\right)$ が得られているとき, 変数 $F$ を変 数 $X_{1}, X_{2}, \ldots, X_{m}$ の関数として推定することを考える. この場合， $X_{1}, X_{2}, \ldots, X_{m}$ について固定し， $F$ に関する 観測方程式として式（2）が得られる.

$$
F=X \beta
$$

ただし， $F$ は定数ベクトル， $X$ は計画行列， $\beta$ は求め る末知量のベクトルであり,

$$
\begin{aligned}
& F=\left[f_{1}, f_{2}, \cdots, f_{n}\right]^{T} \\
& X=\left(\begin{array}{ccccc}
1 & x_{11} & x_{21} & \ldots & x_{m 1} \\
1 & x_{11} & x_{22} & \ldots & x_{m 2} \\
\vdots & \vdots & & \vdots \\
1 & x_{1 n} & x_{2 n} & \ldots & x_{m n}
\end{array}\right) \\
& \beta=\left[\beta_{1}, \beta_{2}, \cdots, \beta_{m}\right]^{T}
\end{aligned}
$$

である.ここで重量行列を単位行列と仮定すると, 式 (2) の観測方程式から最小二乗法により次の正規方程 式が得られる.

$$
X X \beta=X^{\prime} F
$$

ここで

$$
\begin{gathered}
X X=\left(\begin{array}{ccc}
n & \sum x_{1 p} & \ldots \sum x_{m p} \\
\sum x_{1 p} & \sum x_{1 p}{ }^{2} & \ldots \sum x_{1 p} x_{m p} \\
\vdots & \vdots & \vdots \\
\sum x_{m p} & \sum x_{m p} x_{1 p} & \ldots \sum x_{m p}^{2}
\end{array}\right) \\
X F=\left(\begin{array}{c}
\sum f_{p} \\
\sum x_{1 p} f_{p} \\
\vdots \\
\sum x_{m p} f_{p}
\end{array}\right)
\end{gathered}
$$

である. ただし， $\sum$ は $p$ にいての1から $n$ までの総 和である. また, $X X$ は対称行列になっている. した がって, $\beta$ の推定值は, $|X X| \neq 0$ として,

$$
\hat{\beta}=(X X)^{-1} X F
$$

で求められる.ただし，ての $\hat{\beta}$ をいて式(1)により 推定できる力は， $\hat{\beta}$ を決める際に用いた定数べクトル $F$ の要素 $f_{n}$ のとった範囲内の值に限る.

3.2 評価実験 提案した力推定式の評価実験を 行った. 電極のパターンや感圧導電性ゴムの力一抵抗 值特性が不均一の場合, 計測点 1 点毎に式（4）を用 いて $\hat{\beta}$ を決定する必要があるが, この評価実験では 均一と考え, 全計測点に共通の $\hat{\beta}$ を決定する. このと き, 計測点 1 点のみの力と電圧值の関係からでも $\hat{\beta} を$ 決定することができるが, $2 \cdot 1$ で述べたように計測点 間の距離が $0.2 \mathrm{~mm}$ と短く, 1 点のみに力を加えること は困難である. 逆に, 全計測点に力を加えるには精密 な位置合わせが必要となる.そこでこの実験では，人 差し指の中央の $4 \times 4$ 点, 図 3 の (A2,B4) から (A5,B7) を計測対象とし，それよりも一回り小さな面積をもつ 一辺が $5 \mathrm{~mm}$ の立方体の面を，ユニバーサルロボット ハンドの人差し指と親指の指先同士に互いに平行に押 し合う実験を行った.このとき，対象とした計測点は 16 点のみであることから, 全点計測より高速な $500 \mathrm{~Hz}$ の周期で計測を行った. また, 親指の指先にはロード セルを取り付けて, 人差し指に掛かる力の反力を計測 した. 押し合い動作の力は振幅 $15 \mathrm{~N}$, 周期 $12 \mathrm{sec}$ の三 角波として生成し, 正の值をとる半周期 $6 \mathrm{sec}$ を目標 の力として押し合う力をロボットハンドを制御し実現 した. したがって，1 回の押し合い動作で $6 \mathrm{sec}, 3000$ 回の計測となり，ここでは 10 回の押し合い動作を行 い取得した 30000 組の分布型圧力センサとロードセル の出力を式(2)の $F$ と $X$ として, 式 (4) により係数 の推定值 $\hat{\beta}$ を求めた.

次に, 押し合う強さを 2 段階に変化させた実験を行 い, そのときのロードセルの出力と分布型圧力センサ の出力から求めた計測点 16 点分の $f$ の和との比較を 図 5 に示す. 図 5 の縦軸は力, 横軸は時間を示す. 図 5 では, $3.5 \mathrm{~N}$ 程度の小さい力に関してはロードセルと分 布型圧力センサの出力が一致しない部分がある.これ はウレタンゲルが分布型圧力センサに掛かる力を減衰 し, 感圧導電性ゴムまで力が伝わってないことが原因 と考えられる. しかし，それよりも強い力に関しては， 2 段階の力が一定の状態と 2 段階間の力が変化する状 態の両状態において, 各出力はほぼ一致し, 分布型圧 カセンサに加えられる力を精度良く推定できることが 


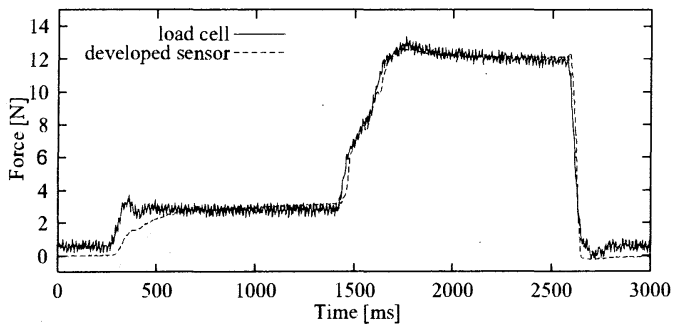

Fig. 5 Outputs of load cell and developed sensor.

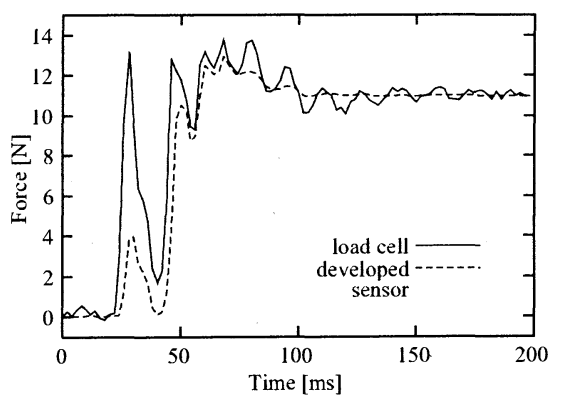

Fig. 6 Impact responses of load cell and developed sensor.

分かる. これは, ロードセルと分布型圧力センサの出 力との重相関係数が 0.99 であることからも分かる.

3.3 応答速度の評価実験応答速度の評価とし て，押し合い動作を高速（約 $1.42 \mathrm{rad} / \mathrm{s}$ ）にした場合の, 各出力を図 6 に示す. 図 6 の縦軸は力, 横軸は時間を 示す. 指を高速で衝突させたため, 時刻 $28 \mathrm{~ms}$ で一度 当たって跳ね返っているのが分かる. このときの分布 型圧力センサの出力は, ロードセルの出力の 3 分の 1 程度であり, 衝撃に対して応答できていない. しかし, その後 $40 \mathrm{~ms}$ から $50 \mathrm{~ms}$ の約 $10 \mathrm{~ms}$ 間で分布型圧力セ ンサの出力が $100 \mathrm{~ms}$ 以降の $11 \mathrm{~N}$ まで達していること から, 分布型圧力センサの応答速度は $10 \mathrm{~ms}$ 程度と評 価できる. 分布型圧力センサの全計測点の計測周期が $20 \mathrm{~ms}$ であることを考慮に入れると，この応答速度は 十分小さいと考えられる.

\section{4. 接触面の形状評価}

$4 \cdot 1$ 形状評価の方法ユニバーサルロボットハ ンドが把持状態を認識するために，分布型圧力センサ から得られた分布情報に基づいて, 把持物の形状認識 を行うことを考える. 特に図 4 に示したような複数の 分布型圧力センサを備えるユニバーサルロボットハン ドが，フィンガの全体を使って物体を把持することを 想定した場合, まず各分布型圧力センサの接触面に関 する形状評価を行い, 次にそれらの結果を組み合わせ て把持物全体の形状認識を行うことが有効であると考

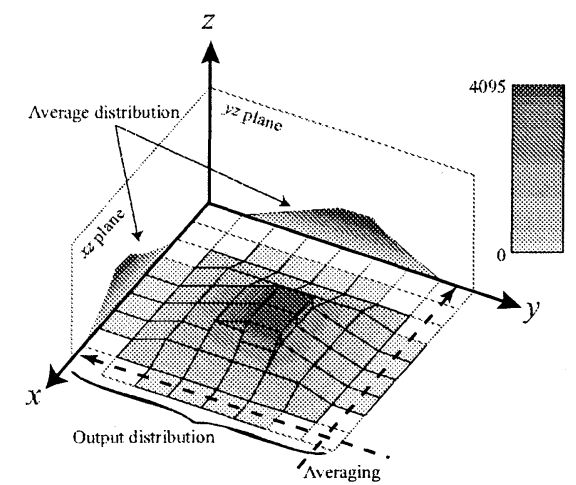

Fig. 7 Example of output distribution and average distribution.

えられる. そこで，ここでは一つの分布情報に対する 接触面の形状評価方法について述べる.

フィンガに搭載した分布型圧力センサは, 対象物が 変形しない場合, 接触面の形状と加えられる力に基づ いて図 7 のような分布を検出する. 温度や湿度などの 環境条件が一定であると仮定し, 接触面に加える力を 一定にすると, 分布は接触面の形状によって決定され る. このとき, 接触面が分布型圧力センサの表面層の ウレタンゲルの厚さよりも小さな起伏で単峰の形状の 場合, 球のような凸状のあれば, その先端部分のみが 大きな值の分布となり, 平板であればゆるやかな分布 となる.

接触面の形状評価を次のような手順で行う．センサ から得られた分布に図7で示すような座標軸を設定し, $x z$ 平面に対して $y$ 軸方向の圧力值の平均をとった平均 分布を求める. $y z$ 平面に対しても同様に平均分布を求 める. 次に, 各平均分布を度数分布とみなし, その尖 度を式（5）によって求める.

$$
\gamma=\sum_{k=1}^{N} z_{k}\left(c_{k}-\mu\right)^{4} /\left(N \sigma^{4}\right)
$$

ただし, 式中の $z_{k}(k=1 \ldots N)$ は分布のデータ, $c_{k}(k=$ $1 \ldots N)$ はデータの階級值, $N$ はデータ数, $\mu$ は平均 值, $\sigma$ は標準偏差である. 尖度は分布が尖っているほ ど值が大きくなり，ゆるやかであれば值が小さくなる. したがって, 分布の尖りの程度を一つの值として表現 できることから, 分布すなわち接触面の形状評価に適 していると考えた.

$4 \cdot 2$ 評価実験 接触面の形状評価に関する実験 を行った. ユニバーサルロボットハンドの前にテスト ピースを固定し, 分布型圧力センサにそのテストピー スが接触するようフィンガの関節を動作させた. ただ し, 今回の実験で対象とするのは人差し指の中節に適 


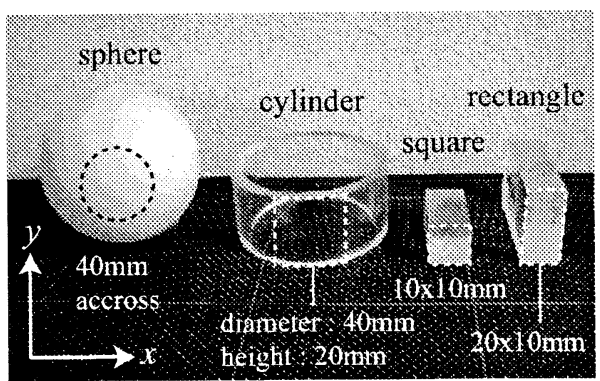

Fig. 8 Test pieces for this experiment.

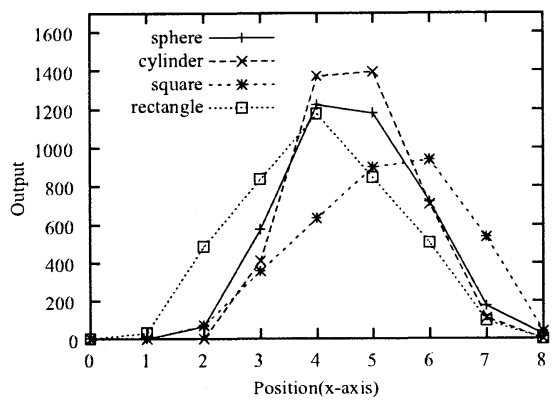

Fig. 9 Average distribution of $x z$ plane.

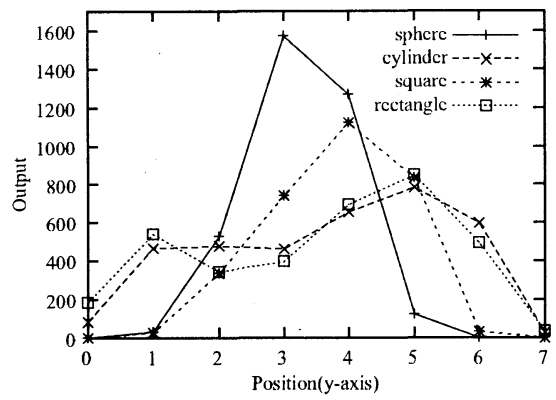

Fig. 10 Average distribution of yz plane.

用した計測点数が 70 点のセンサである. テストピー スは図 8 に示すような大きさの 4 種類とした．実験で は，図 8 における各テストピースの点線で示す面と分 布型圧力センサの表面が平行かつ図 8 で示す座標軸と 図 7 で示す座標軸が一致するよう接触させた。

実験の結果得られた分布から求めた $\mathrm{xz}$ 平面の平均 分布を図 9 に, $\mathrm{yz}$ 平面の平均分布を図 10 に示す.た だし，センサに加えられた圧力をほぼ一定にするため, 各平均分布は元の分布の各值の合計が約 30000 の分布 から求めた. 実験で用いた分布型圧力センサの電極数 が, $\mathrm{x}$ 軸方向に 9 本, $\mathrm{y}$ 軸方向に 8 本あることから, 図 9 と図 10 の横軸はそれらの本数に応じた要素数となっ ている. 緹軸は $\mathrm{AD}$ 変換ボードの出力值である.

xz 平面を示す図 9 では, sphere と cylinder が同じよ
Table 1 Averages and standard deviations of kurtosis of average distributions

\begin{tabular}{c|l|l|l|l|l}
\hline \multicolumn{2}{c|}{ test piece } & sphere & cylinder & square & rectangle \\
\hline \hline \multirow{2}{*}{$\mathrm{xz}$} & AVE & 2.67 & 2.68 & 2.40 & 2.38 \\
\cline { 2 - 6 } & SD & 0.026 & 0.057 & 0.032 & 0.011 \\
\hline \multirow{2}{*}{$\mathrm{yz}$} & AVE & 2.71 & 1.96 & 2.38 & 1.94 \\
\cline { 2 - 6 } & SD & 0.081 & 0.026 & 0.067 & 0.045 \\
\hline
\end{tabular}

うな分布となっているが，これらは直径 $40 \mathrm{~mm}$ の曲面 形状にもとづく平均分布である. また，yz平面を示 す図 10 では cylinder と rectangle が同じような分布と なっているが，これらは長さ $20 \mathrm{~mm}$ の平面形状にもと づく平均分布である.これらの結果は, 開発した分布 型圧力センサが各テストピースの接触面の形状に応じ た圧力分布を計測できることを示している.

次に, 同じ実験を 5 回行ったときに得られた各平均 分布の尖度の平均值と標準偏差を表 1 に示す. sphere の両平面と cylinder の $\mathrm{xz}$ 平面はいづれも直径 $40 \mathrm{~mm}$ の曲面形状であるが, それら平均分布の尖度も近い值 である. 同様に, 長さ $20 \mathrm{~mm}$ の平面である cylinder と rectangle の $\mathrm{yz}$ 平面, さらには長さ $10 \mathrm{~mm}$ の平面であ る squareの両平面と rectangle の $\mathrm{xz}$ 平面の平均分布の 尖度も近い值である. また，標準偏差に注目するとそ れぞれの平均值の $3 \%$ より小さい值となっており, 各 尖度がばらつきが小さく信頼性の高い值であることを 示している．これらの結果から，接触面の形状を尖度 で評価できることがわかった.

\section{5. おりに}

ユニバーサルロボットハンドに適用することを目的 とした分布型圧力センサについて述べた：この分布型 圧力センサはウレタンゲルによる柔軟な表面層をもち, シート状の素材のみからなる単純な構造に特長がある. 計测精度と応答速度に関する実験を行い, その結果, センサ面に掛かる力を精度良く推定でき，センサの応 答速度が全点計測時の周期に比べて十分小さいことを を示した．さらに，接触面の形状を評価する方法につ いて述べた．実験の結果，その方法と尖度という指標 を用いることで評価が可能なことを示した.

本稿で述べた実験やその結果は, いづれもユニバー サルロボットハンドに適用した一つの分布型圧力セン サによるものである. 現在, 複数の分布型圧力センサ を用いての把持の状態，把持物体の認識を行い，その 結果からユニバーサルロボットハンドを制御する手法 について研究を進めている. 


\section{文献}

(1) Inoue, H., Hirukawa, H., HRP: Humanoid Robotics Project of MITI, Journal of the Robotics Society of Japan, Vol.19, No.1(2001), pp.2-7

(2) John M. Hollerbach, Stephen C. Jacobsen, Anthropomorphic robots and human interactions, Proceeding 1st International Symposium on Humanoid Robots(1996), pp.8391.

(3) Mouri,T., Kawasaki,H., Yoshikawa, K., Takai, J., Ito,S., Anthropomorphic Robot Hand: Gifu Hand III, Proceeding of International Conference ICCAS2002 (2002) pp.12881293.

(4) Maeno, T., Structure and Function of Finger Pad and Tactile Receptors, Journal of the Robotics Society of Japan, Vol.18, No.6(2000), pp.14-17.

(5) Hoshi, T., Shinoda, H., Tactile Sensing Using Non-Linear Elastic Property, 2005 JSME Conference on Robotics and Mechatronics, 2P1-N-104, (2005)

(6) Motoo, K., Arai, F., Fukuda, T., Piezoelectric VibrationType Tactile Sensor Using Elasticity and Viscosity Change of Structure, Journal of the Robotics Society of Japan, Vol.24, No.3 (2006), pp.408-415.

(7) Murakami, K., Hasegawa, T., Tactile Sensing of Edge Direction of an Object using a Robotic Fingertip with Soft Skin, Journal of the Robotics Society of Japan, Vol.24, No.2(2006), pp.240-247.

(8) Yamada, D., Maeno, T., Yamada, Y., Development of Elastic Robot Finger having Ridges which can Detect a
Distribution of Contact Condition, Journal of the Japan Society of Mechanical Engineers, Vol.70, No.690(2004), pp.560-566.

(9) Tada,Y., Hosoda,K., Asada,M., Anthropomorphic Soft Fingertip with Tactile Receptors in the Skin, Journal of the Robotics Society of Japan, Vol.23, No.4(2005), pp.482487.

(10) Nakamoto, H., Saiki, T., Kitagawa, Y., Pressure Distribution Sensor, Combined Flexible Material and Conductive Rubber for Robot Hand, Journal of the Robotics Society of Japan, Vol.23, No.3 (2005), pp.360361.

(11) Johnston, D., Zhang, P., Hollerbach, J.M., and Jacobsen, S.C. : A full tactile sensing suite for dextrous robot hands and use in contact force control, Proceeding IEEE International Conference Robotics and Automation(1996), pp.3222-3228.

(12) Ishihara, T., Namiki, A., Ishikawa, M., Shimojo, M., High-speed grasp and manipulation of a pen-shaped object using a high-speed multifingered hand with highspeed tactile sensor, 2006 JSME Conference on Robotics and Mechatronics, 1A1-B39(2006)

(13) INABA RUBBER Co., Ltd Home Page, URL://www.inaba-rubber.co.jp/index.html

(14) Shimojo, M., Ishikawa, M., Kanaya, K., A Flexible High Resolution Tactile Imager with Video Signal Output, Journal of the Japan Society of Mechanical Engineers, Vol.57, No.537(1991), pp.150-156. 